\title{
Magnetite-Containing Sulfonated Polyacrylamide as a Nanocatalyst for the Preparation of Biscoumarins
}

\author{
Kaveh Parvanak Boroujeni, ${ }^{1, *}$ Shahla Hadizadeh, ${ }^{1}$ Sodabeh Hasani, ${ }^{1}$ \\ Abdulhamid Fadavi ${ }^{2}$ and Mansooreh Shahrokh ${ }^{1}$ \\ ${ }^{1}$ Department of Chemistry, Shahrekord University, P.O. Box 88186-34141 Shahrekord, Iran \\ ${ }^{2}$ Department of Chemistry, Marvdasht Branch, Islamic Azad University, Marvdasht, Iran \\ * Corresponding author: E-mail: parvanak-ka@asci.sku.ac.ir \\ Tel.: +0098-38-32324401; fax: 0098-38-32324419
}

Received: 12-04-2017

\begin{abstract}
Magnetite-containing sulfonated polyacrylamide was easily prepared through polymerization of the corresponding monomers followed by the reaction with $\mathrm{Fe}_{3} \mathrm{O}_{4}$ nanoparticles. The characterization of the obtained catalyst was performed by Fourier transform infrared spectroscopy (FT-IR), thermal gravimetric analysis (TGA), scanning electron microscopy (SEM), energy dispersive spectroscopy (EDS), X-ray diffraction (XRD), and vibrating sample magnetometer (VSM). The acidic $\mathrm{SO}_{3} \mathrm{H}$ moiety was found to be $1.1 \mathrm{mmol}$ per gram of the obtained polymer. The catalytic activity of the polymer was examined for the synthesis of biscoumarin derivatives by two-component one-pot domino Knoevenagel-type condensation/Michael reaction between aldehydes and 4-hydroxycoumarin. Biscoumarins were obtained in high to excellent yields in short time. The work-up procedure of this reaction was very simple. The catalyst is stable (as a bench top catalyst) with easy-handling and it can be used again.
\end{abstract}

Keywords: Nanoparticles; Radical polymerization; Magnetism and magnetic properties; Catalysts; Biscoumarins

\section{Introduction}

Due to the unique characteristics of magnetite $\mathrm{Fe}_{3} \mathrm{O}_{4}$ nanoparticles, they have attracted great attention in the field of biology, medicine, electronics, and catalytic processes. ${ }^{1}$ However, $\mathrm{Fe}_{3} \mathrm{O}_{4}$ nanoparticles respond to external stimuli such as the $\mathrm{pH}$ value and temperature, due to the $\mathrm{pH}-$ and temperature-sensitive properties. Also, they are unstable in the presence of oxygen at light and coagulation of nanoparticles is usually unavoidable during their use. Therefore, there has been a considerable research effort to stabilize $\mathrm{Fe}_{3} \mathrm{O}_{4}$ nanoparticles through coating the surface of such nanoparticles with carbon, precious metals, silica, and polymers. In this regard, the use of polymers containing a functional group that binds strongly to the nanoparticles through covalent or electrostatic interactions has been the subject of great interest to researchers. ${ }^{2}$ For this purpose, a variety of polymeric materials, such as poly(glycerol monoacrylate), polyaniline, polyacrylamide, poly( $N$-vinyl-2-pyrrolidone), poly(para-phenylenediamine), poly(vinylalcohol), poly(ether-amide), polypyr- role, and chitosan as well as polymers containing polar pendant groups, such as carboxylate, phosphate, or sulfate groups have been used. ${ }^{3-6}$

Recently, magnetic nanomaterials have emerged as a promising catalysts for various organic and inorganic reactions because of their large surface-to-volume ratio relative to bulk materials and hence the large ratio of atoms available at the surface. ${ }^{2}$ These types of catalysts can be easily separated using an external magnet and their catalytic activity remains high even after several reaction cycles. Magnetite catalysts were used as efficient catalytic systems in many chemical transformations including asymmetric hydrogenation of aromatic ketones, ${ }^{7}$ the desymmetrization of racemic 1,2-diols through asymmetric benzoylation, ${ }^{8}$ synthesis of 14 -arylor alkyl-14H-dibenzo[ $a, j]$ xanthenes and 1,8-dioxooctahydroxanthene derivatives, ${ }^{9,10}$ Sonogashira cross-coupling reaction, ${ }^{11}$ synthesis of tetrahydrobenzo[ $[a]$ xanthen-11-ones, ${ }^{12} \mathrm{C}-\mathrm{N}$ bond formation via aza-Michael addition, ${ }^{6}$ and preparation of functionalized tricarboxamide derivatives. ${ }^{13}$ 
Coumarin and its derivatives are important as anti$\mathrm{HIV}$, antibiotic, antifungal, antibacterial, antioxidant, anticancer, and anticoagulant agents. ${ }^{14-16}$ Among various derivatives of coumarin, biscoumarins have aroused considerable interest. These important compounds were usually prepared from the reaction of aldehydes with 4-hydroxycoumarin. Several types of catalysts were introduced previously for this reaction, such as piperidine, ${ }^{17}$ tetrabutylammonium bromide, ${ }^{18} \mathrm{I}_{2},{ }^{19}$ sodium dodecyl sulfate, ${ }^{20} 1$ buthyl-3-methylimidazolium tetrafluoroborate, ${ }^{21} 1$-ethyl3-(3-sulfopropyl)-benzimidazolium trifluoromethanesulfonate, ${ }^{22}$ para-dodecylbenzenesulfonic acid/piperidine, ${ }^{23}$ 3-methyl-1-(4-sulfonic acid)butylimidazolium hydrogen sulfate, ${ }^{24} \mathrm{~B}\left(\mathrm{HSO}_{4}\right)_{3},{ }^{25}$ polyvinylpyrrolidone-supported nickel nanoparticles, ${ }^{26}$ poly(4-vinylpyridine)-supported ionic liquids, ${ }^{27,28}$ and cellulose sulfonic acid. ${ }^{29}$ Also, biscoumarin derivatives have been prepared by the condensation of 1,2-diols and 4-hydroxycoumarin using $\mathrm{Pb}(\mathrm{OAc})_{4}{ }^{30}$ However, many of these methods have some drawbacks, such as a requirement for either a long reaction time or harsh reaction conditions, provide low yields, include laborious work-up procedures, inefficiency of method when aliphatic aldehydes are used in the reaction, and the use of unrecyclable, hazardous or difficult to handle catalysts.

In continuation of our research on the synthesis and applications of polymer-supported catalysts and nanocomposites, ${ }^{27,28,31,32}$ we now wish to introduce poly(2acrylamido-2-methyl propane sulphonic acid-co-acrylamide) containing $\mathrm{Fe}_{3} \mathrm{O}_{4}$ nanoparticles (poly(AMPS-coAA) $\left.@ \mathrm{Fe}_{3} \mathrm{O}_{4}\right)$ as a heterogeneous catalyst for the synthesis of biscoumarin derivatives. Poly(AMPS-co-AA)@$\mathrm{Fe}_{3} \mathrm{O}_{4}$ was prepared by benzoyl peroxide $\left(\mathrm{Bz}_{2} \mathrm{O}_{2}\right)$ initiated polymerization of 2-acrylamido-2-methylpropane sulphonic acid (AMPS) with acrylamide (AA) followed by reaction with $\mathrm{Fe}_{3} \mathrm{O}_{4}$ nanoparticles

\section{Experimental}

\section{1. Materials and Methods}

All chemicals were either prepared in our laboratory or were purchased from Merck and Fluka. Reaction monitoring and purity determination of the products were accomplished by GLC or TLC on silica-gel polygram $\mathrm{SILG} / \mathrm{UV}_{254}$ plates. Gas chromatography was carried out on Shimadzu GC 14-A. IR spectra were obtained by a Shimadzu model 8300 FT-IR spectrophotometer. ${ }^{1} \mathrm{H}$ NMR spectra were recorded on $400 \mathrm{MHz}$ spectrometer in $\mathrm{CDCl}_{3}$. TGA was carried out on a Stanton Redcraft STA-780 with a $20^{\circ} \mathrm{C} / \mathrm{min}$ heating rate. Melting points were determined on a Fisher-Jones melting-point apparatus. XRD patterns were recorded by a Phillips X-ray diffractometer using graphite monochromatized $\mathrm{Cu} \mathrm{K} \alpha$ radiation. A morphological study of the synthesized products was carried out directly by a Hitachi S4160 field emission scanning electron microscope (FESEM). Room temperature magnetic properties were investigated by Lakeshore device in an applied magnetic field sweeping between \pm 8000 Oe.

\section{2. Preparation of $\mathrm{Fe}_{3} \mathrm{O}_{4}$ Nanoparticles}

To a solution of ferrous chloride $\left(\mathrm{FeCl}_{2}, 1 \mathrm{M}\right)$, Na$\mathrm{OH}(4 \mathrm{M})$ was added dropwise with vigorous stirring to produce a black solid product (magnetite $\mathrm{Fe}_{3} \mathrm{O}_{4}$ nanoparticles) when the reaction media reaches $\mathrm{pH} 12$. The resulting nanoparticles were carefully decanted and washed repeatedly with doubly distilled water and absolute ethanol and then dried under vacuum at room temperature.

\section{3. Synthesis of (Poly(AMPS-co-AA) $@ \mathrm{Fe}_{3} \mathrm{O}_{4}$ )}

First, in a round bottomed flask $(50 \mathrm{~mL})$ equipped with a reflux condenser, $0.051 \mathrm{~g}(0.214 \mathrm{mmol})$ of $\mathrm{Bz}_{2} \mathrm{O}_{2}$ was added to a solution of acrylamide (15 mmol, $1.066 \mathrm{~g})$, AMPS (6.42 mmol, $1.330 \mathrm{~g})$, and ethanol $(25 \mathrm{~mL})$ and the mixture was refluxed for $5 \mathrm{~h}$. Afterwards, $\mathrm{Fe}_{3} \mathrm{O}_{4}$ nanoparticles (12 mmol, $2.78 \mathrm{~g}$ ) were added to the mixture and refluxed for $1 \mathrm{~h}$. Then, the obtained solid was easily separated from the reaction mixture by an external magnet and washed with deionized water and ethanol three times and dried overnight in vacuum at $80^{\circ} \mathrm{C}$.

The same procedure applied for the preparation of poly(AMPS-co-AA) $@ \mathrm{Fe}_{3} \mathrm{O}_{4}$ was also repeated for the preparation of poly(AMPS-co-AA) without addition of $\mathrm{Fe}_{3} \mathrm{O}_{4}$ nanoparticles. In this case, the polymer formed in the first step was collected by filtration, washed three times with ethanol, and dried overnight in vacuum at $60^{\circ} \mathrm{C}$.

\section{4. Preparation of 3,3'-(4-Nitrobenzylide- ne)-bis-(4-hydroxycoumarin) as a Typi- cal Procedure for the Synthesis of Bis- coumarines}

A mixture of $1 \mathrm{mmol}$ of 4-nitrobenzaldehyde, 2 mmol of 4-hydroxycoumarin, $0.04 \mathrm{mmol}$ of poly(AMPSco-AA) $@ \mathrm{Fe}_{3} \mathrm{O}_{4}$, and $3 \mathrm{~mL}$ of toluene was heated at 90 ${ }^{\circ} \mathrm{C}$. After the completion of the reaction (monitored by TLC), the catalyst was removed by an external magnet and washed with toluene $(2 \times 5 \mathrm{~mL})$ and the filtrate was concentrated on a rotary evaporator under reduced pressure. The crude product was recrystallized from ethanol to give the pure 3,3'-(4-nitrobenzylidene)-bis-(4-hydroxycoumarin).

\section{Results and Discussion}

\section{1. Synthesis of Poly(AMPS-co-AA)@ $\mathrm{Fe}_{3} \mathrm{O}_{4}$}

Poly(AMPS-co-AA) @ $\mathrm{Fe}_{3} \mathrm{O}_{4}$ was synthesized by free radical polymerization of AA and AMPS monomers 
<smiles>C=CC(=O)NC(C)(C)C[SbH](=O)[O-]</smiles>

(AMPS)

(AA)

Scheme 1. Synthetic pathways for poly(AMPS-co-AA) containing $\mathrm{Fe}_{3} \mathrm{O}_{4}$ nanoparticles.

in the presence of $\mathrm{Bz}_{2} \mathrm{O}_{2}$ initiator followed by the reaction with $\mathrm{Fe}_{3} \mathrm{O}_{4}$ nanoparticles (Scheme 1). The acidic sites loading in poly(AMPS-co-AA) @ $\mathrm{Fe}_{3} \mathrm{O}_{4}$ obtained by means of acid-base titration was found to be $1.1 \mathrm{mmol} / \mathrm{g} .{ }^{27,28}$ For comparison purposes, poly(AMPS-co-AA) was also prepared via the same procedure applied for the preparation of poly(AMPS-co-AA) @ $\mathrm{Fe}_{3} \mathrm{O}_{4}$ without addition of $\mathrm{Fe}_{3} \mathrm{O}_{4}$.

\section{2. Characterization of Poly (AMPS-co-AA)@ $\mathrm{Fe}_{3} \mathrm{O}_{4}$}

Figure 1 shows the FT-IR spectra of $\mathrm{Fe}_{3} \mathrm{O}_{4}$, poly(AMPS-co-AA), and poly(AMPS-co-AA) @ $\mathrm{Fe}_{3} \mathrm{O}_{4}$. The IR spectral data of $\mathrm{Fe}_{3} \mathrm{O}_{4}$ show two characteristic peaks at 425 and $567 \mathrm{~cm}^{-1}$, which are due to $\mathrm{Fe}-\mathrm{O}$ stretching vibrations (Figure 3a). ${ }^{31}$ As shown in Figure $3 b$, the IR spectrum of poly(AMPS-co-AA) exhibits peaks at 3346 and $3428 \mathrm{~cm}^{-1}$ (N-H vibrations of amide groups), $1663 \mathrm{~cm}^{-1}$ ( $\mathrm{C}=\mathrm{O}$ vibrations of carbonyl groups), and 1208 $\mathrm{cm}^{-1}$ ( $\mathrm{S}=\mathrm{O}$ vibrations of sulfonic groups). ${ }^{27,28} \mathrm{Also}$, the IR spectrum of poly(AMPS-co-AA) @ $\mathrm{Fe}_{3} \mathrm{O}_{4}$ displayed peaks at 3422,1658 , and $1185 \mathrm{~cm}^{-1}$ which are assigned to stretc-

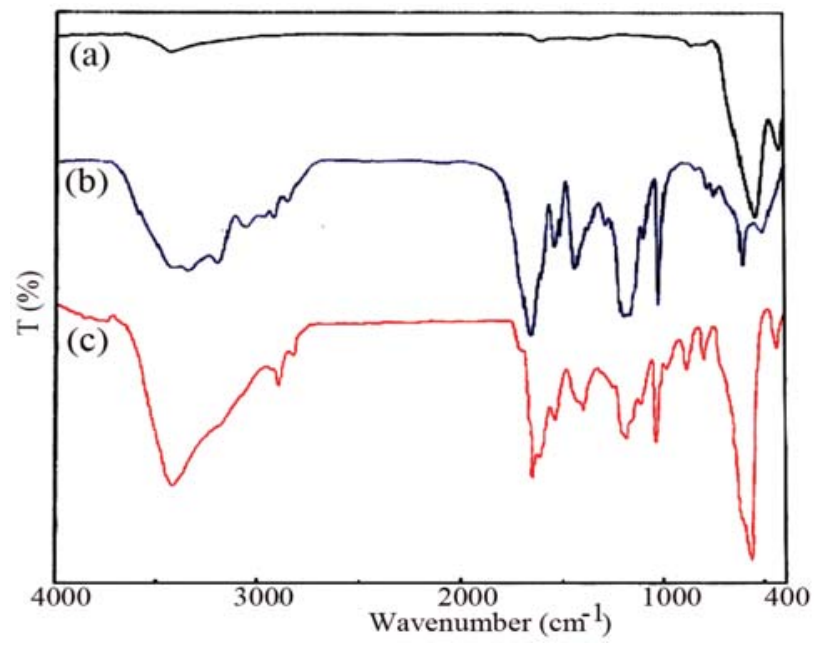

Figure 1. FT-IR spectra of $\mathrm{Fe}_{3} \mathrm{O}_{4}$ (a), poly (AMPS-co-AA) (b), and poly(AMPS-co-AA) $@ \mathrm{Fe}_{3} \mathrm{O}_{4}$ (c).

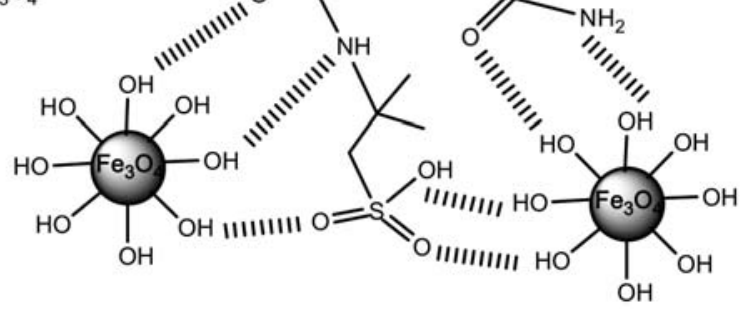

(Poly (AMPS-co-AA) @ $\mathrm{Fe}_{3} \mathrm{O}_{4}$ )

hing vibrations of $\mathrm{NH}$ and $\mathrm{NH}_{2}, \mathrm{C}=\mathrm{O}$, and $\mathrm{S}=\mathrm{O}$, respectively (Figure $3 \mathrm{~b}$ ). In IR spectrum of poly(AMPS-coAA) $@ \mathrm{Fe}_{3} \mathrm{O}_{4}$ the appearance of peaks at 429 and 574 $\mathrm{cm}^{-1}$, attributed to $\mathrm{Fe}-\mathrm{O}$ stretching vibrations, indicates that $\mathrm{Fe}_{3} \mathrm{O}_{4}$ nanoparticles were attached to the polymer chains.

Thermal data obtained from TGA analysis are presented in Figure 2. In TGA curves of $\mathrm{Fe}_{3} \mathrm{O}_{4}$ and poly(AMPS-co-AA) @ $\mathrm{Fe}_{3} \mathrm{O}_{4}$ a slow mass loss observed between room temperature and $150{ }^{\circ} \mathrm{C}$ could be related to the removal of surface adsorbed water, the remaining solvent, and residual monomers. The second step weight loss starting from $180{ }^{\circ} \mathrm{C}$ in TGA curve of $\mathrm{Fe}_{3} \mathrm{O}_{4}$ could be attributed to thermal crystal phase transformations of $\mathrm{Fe}_{3} \mathrm{O}_{4}$ to $\mathrm{Fe}_{2} \mathrm{O}_{3}$. In the case of poly(AMPS-co-AA) @ $\mathrm{Fe}_{3} \mathrm{O}_{4}$ the second step weight loss starting from $180{ }^{\circ} \mathrm{C}$ could be related to thermal oxidation of $\mathrm{Fe}_{3} \mathrm{O}_{4}$ and also the decomposition of amide and 2-methylpropane sulphonic acid pendant groups. The last weight losses in TGA curves of poly(AMPS-co-AA) @ $\mathrm{Fe}_{3} \mathrm{O}_{4}$ at about $360{ }^{\circ} \mathrm{C}$ was likely due to the degradation of the polymer backbone. Based on the char yield of poly(AMPS-co-AA) @ $\mathrm{Fe}_{3} \mathrm{O}_{4}$ at $800{ }^{\circ} \mathrm{C}$ and assuming that the final residues are mainly $\mathrm{Fe}_{3} \mathrm{O}_{4}$ and

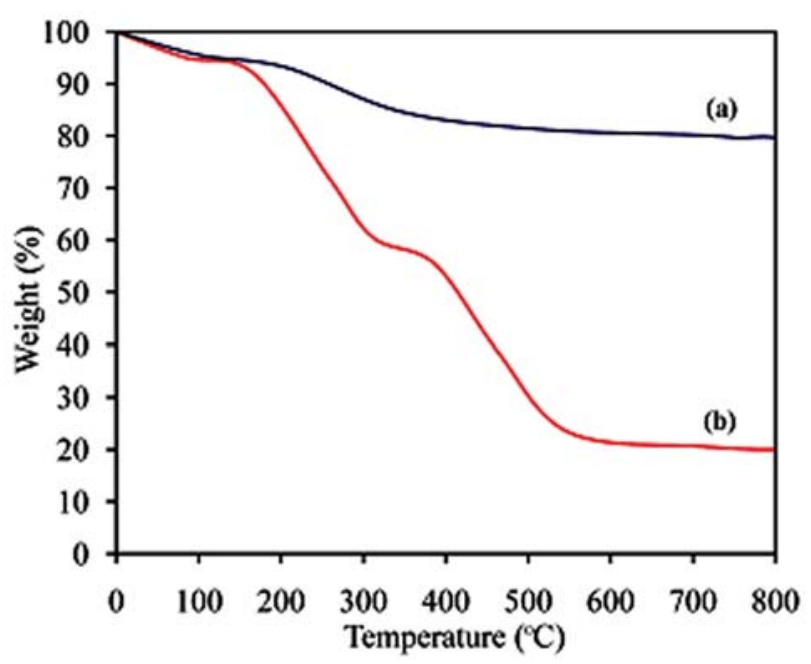

Figure 2. TGA curves of $\mathrm{Fe}_{3} \mathrm{O}_{4}$ (a) and poly(AMPS-co-AA)@ $\mathrm{Fe}_{3} \mathrm{O}_{4}(\mathrm{~b})$. 
$\mathrm{Fe}_{2} \mathrm{O}_{3}$, the anchoring amount of $\mathrm{Fe}_{3} \mathrm{O}_{4}$ in poly(AMPS-co$\mathrm{AA}) @ \mathrm{Fe}_{3} \mathrm{O}_{4}$ is about 20 wt. $\%$. The relatively high char yield of poly(AMPS-co-AA) $@ \mathrm{Fe}_{3} \mathrm{O}_{4}$ also indicates that the incorporation of $\mathrm{Fe}_{3} \mathrm{O}_{4}$ into the polymer chains im-
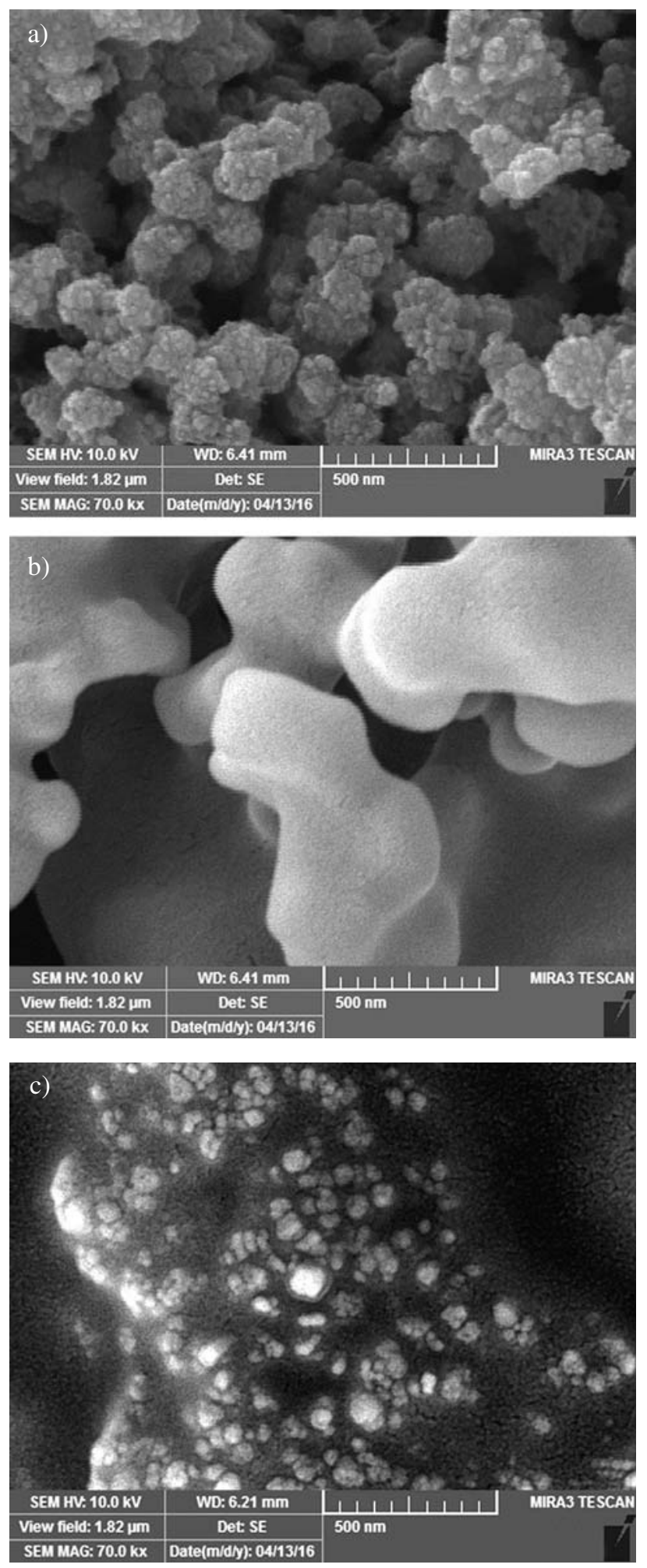

Figure 3. SEM photographs of $\mathrm{Fe}_{3} \mathrm{O}_{4}$ (a), poly(AMPS-co-AA) (b), and poly(AMPS-co-AA) @ $\mathrm{Fe}_{3} \mathrm{O}_{4}$ (c). parts significant thermal stability to the resulting poly(AMPS-co-AA)@ $\mathrm{Fe}_{3} \mathrm{O}_{4}$.

Figure 3 shows the SEM images of synthesized samples. Figure $3 \mathrm{a}$ indicates that the most of $\mathrm{Fe}_{3} \mathrm{O}_{4}$ nanoparticles are monodisperse and have a spherical crystal morphology with a diameter range between $40-50 \mathrm{~nm}$. With comparison of SEM micrographs of the magnetic poly(AMPS-co-AA) (Figure 3c) with poly(AMPS-coAA) (Figure 3b), it can be deduced that the polymer chains clearly loaded on $\mathrm{Fe}_{3} \mathrm{O}_{4}$ nanoparticles.

EDS analyses of poly(AMPS-co-AA) and poly(AMPS-co-AA) $@ \mathrm{Fe}_{3} \mathrm{O}_{4}$ are shown in Figure 4. EDS of poly(AMPS-co-AA) @ $\mathrm{Fe}_{3} \mathrm{O}_{4}$ shows that there are no impurities in this catalyst and confirms the presence of $\mathrm{S}$ and Fe elements (Figure $4 b$ ).

Figure 5 shows the XRD patterns of $\mathrm{Fe}_{3} \mathrm{O}_{4}$ nanoparticles and poly(AMPS-co-AA)@ $\mathrm{Fe}_{3} \mathrm{O}_{4}$. The XRD pattern of $\mathrm{Fe}_{3} \mathrm{O}_{4}$ nanoparticles (Figure 5a) exhibited the peaks at $2 \theta=30.21,35.52,43.32,53.61,57.09,62.63,71.19$, and $74.20^{\circ}$ that could be assigned to $220,111,311,400,422$, 511, 440, and 442 planes of $\mathrm{Fe}_{3} \mathrm{O}_{4}$, respectively. Due to
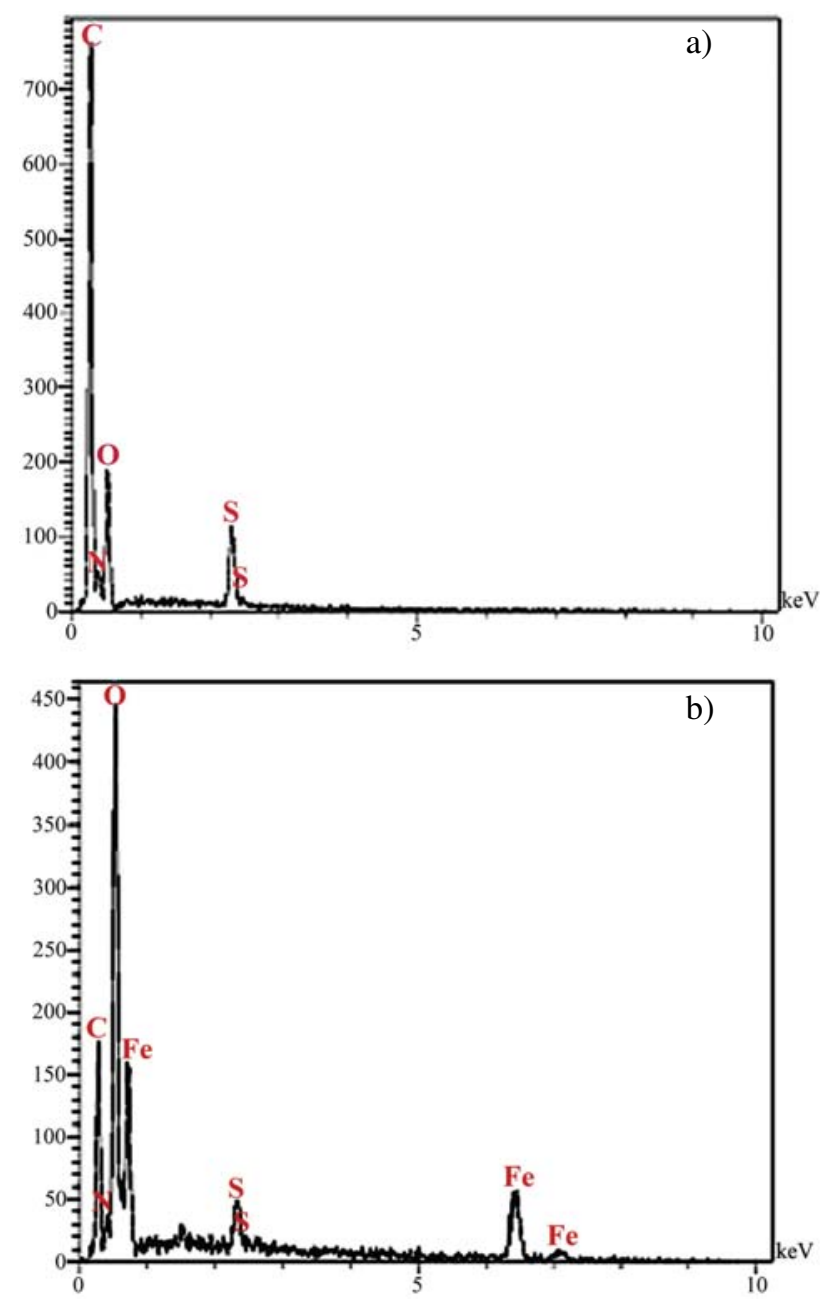

Figure 4. EDS spectra of poly(AMPS-co-AA) (a) and poly(AMPS -co-AA)@ $\mathrm{Fe}_{3} \mathrm{O}_{4}$ (b). 
the agreement with the card no. 88-0315, it seems the resultant particles are pure magnetite. The crystal size of the particles was calculated by line broadening from the XRD pattern using the Debye-Scherrer formula and they were estimated to be between $20-25 \mathrm{~nm}$. The weaker diffraction lines of poly(AMPS-co-AA) $@ \mathrm{Fe}_{3} \mathrm{O}_{4}$ (Figure 5b) compared with $\mathrm{Fe}_{3} \mathrm{O}_{4}$ nanoparticles indicate that the $\mathrm{Fe}_{3} \mathrm{O}_{4}$ nanoparticles were covered by amorphous polymer.

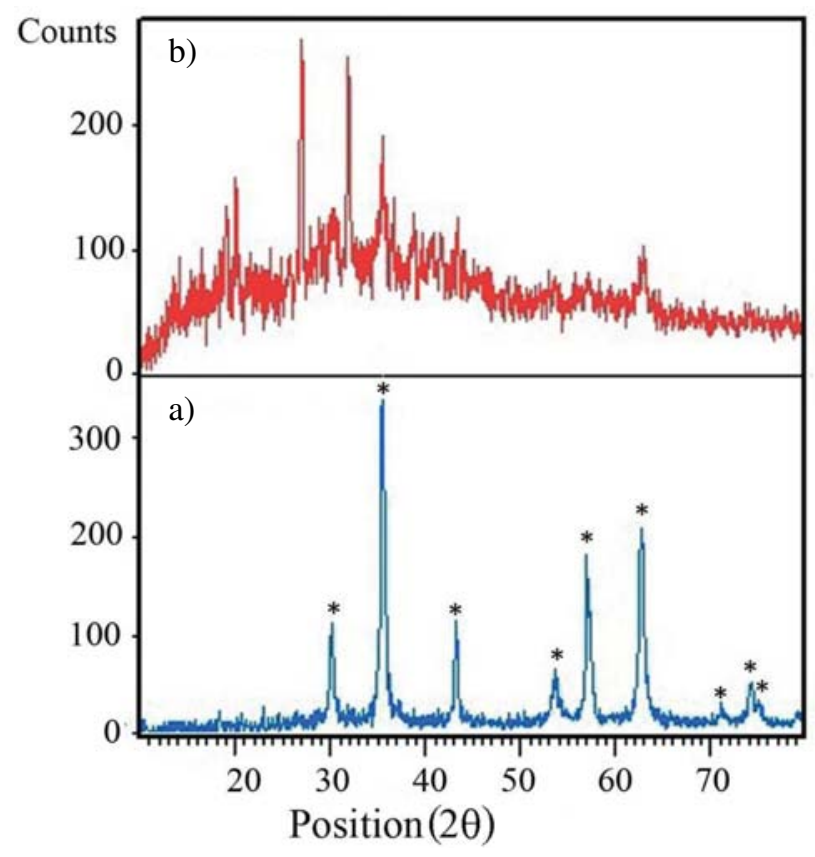

Figure 5. The XRD patterns of $\mathrm{Fe}_{3} \mathrm{O}_{4}$ nanoparticles (a) and poly(AMPS-co-AA)@ $\mathrm{Fe}_{3} \mathrm{O}_{4}$ (b).

Magnetic properties of the samples were also studied. Hysteresis loops of $\mathrm{Fe}_{3} \mathrm{O}_{4}$ nanoparticles and poly(AMPS-co-AA) @ $\mathrm{Fe}_{3} \mathrm{O}_{4}$ are depicted in Figure 6. The $\mathrm{Fe}_{3} \mathrm{O}_{4}$ nanoparticles exhibited ferromagnetic behavior in saturation magnetization of $63.53 \mathrm{emu} / \mathrm{g}$ and a coactivity of 1.76 Oe at room temperature (Figure 6a).

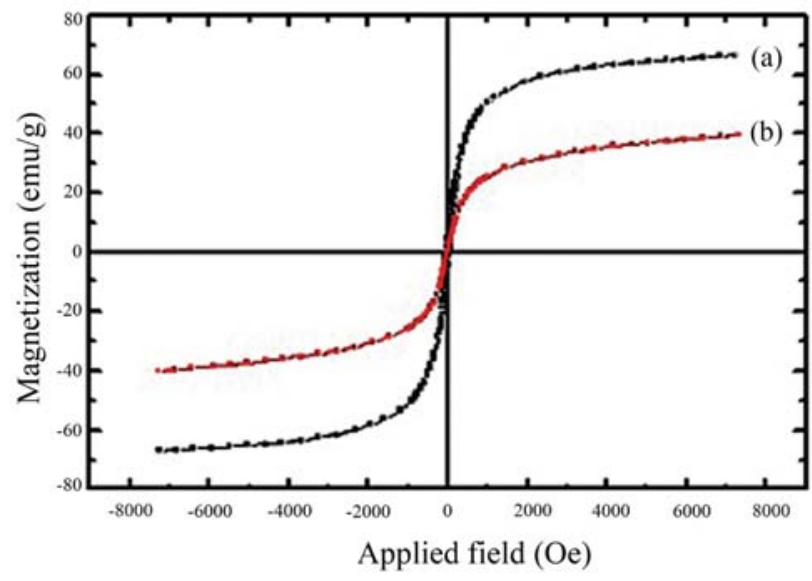

Figure 6. Magnetization curves for $\mathrm{Fe}_{3} \mathrm{O}_{4}$ nanoparticles (a) and poly(AMPS-co-AA) @ $\mathrm{Fe}_{3} \mathrm{O}_{4}$ (b).
The results showed that the saturation magnetization value of poly(AMPS-co-AA) $@ \mathrm{Fe}_{3} \mathrm{O}_{4}$ (Figure 6b, $48 \mathrm{emu} / \mathrm{g}$ ) was lower than $\mathrm{Fe}_{3} \mathrm{O}_{4}$ nanoparticles due to the interaction of polymer and $\mathrm{Fe}_{3} \mathrm{O}_{4}$ nanoparticles.

\section{3. Catalytic Application of Poly(AMPS-co- $\mathrm{AA}) @ \mathrm{Fe}_{3} \mathrm{O}_{4}$ in the Synthesis of Biscou- marins}

After synthesis of poly(AMPS-co-AA) $@ \mathrm{Fe}_{3} \mathrm{O}_{4}$ we tried to convert aldehydes to the corresponding biscoumarins in the presence of this catalyst. To optimize the reaction conditions, initially, the condensation reactions of benzaldehyde $(1 \mathrm{mmol})$ with 4-hydroxycoumarin (2 $\mathrm{mmol}$ ) in the presence of different molar ratios of poly(AMPS-co-AA) @ $\mathrm{Fe}_{3} \mathrm{O}_{4}$ in various solvents and also under solvent free conditions were studied. The results indicate that this reaction goes well in toluene and the product was obtained in excellent yield in the presence of $0.04 \mathrm{mmol}$ of the catalyst at $90{ }^{\circ} \mathrm{C}$. After establishing the optimal conditions, in order to prove the generality of this method, a variety of aromatic aldehydes bearing electrondeficient or electron-rich substituents on the aromatic ring (Table 1, entries 1-7), heteroaromatic aldehydes such as 2-thienyl and 2-furanyl carbaldehyde (entries 8, 9), and aliphatic aldehydes (entries 10-12) reacted with 4hydroxycoumarin to give the corresponding biscoumarin products in excellent yields. ${ }^{1} \mathrm{H}$ NMR spectrum of the product 3,3'-(4-nitrobenzylidene)-bis-(4-hydroxycoumarin) is shown in Figure 7.

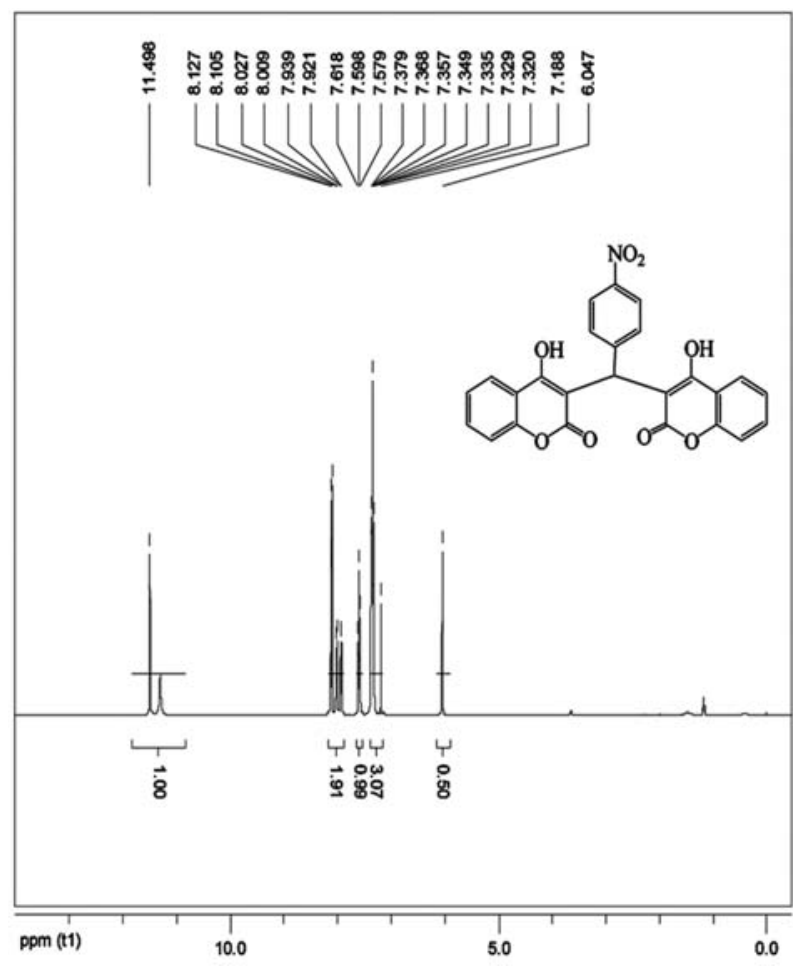

Figure 7. ${ }^{1} \mathrm{H}$ NMR spectrum of the 3,3'-(4-nitrobenzylidene)-bis(4-hydroxycoumarin). 
Table 1: Synthesis of biscoumarin derivatives catalyzed by poly(AMPS-co-AA) $@ \mathrm{Fe}_{3} \mathrm{O}_{4}$.
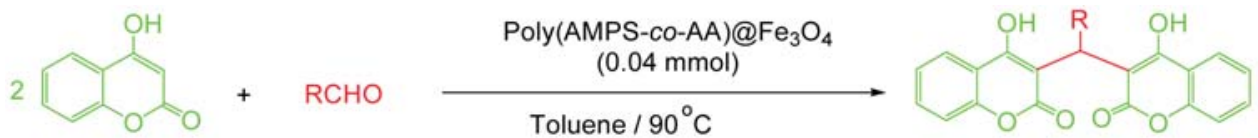

\begin{tabular}{llcccr}
\hline Entry & Aldehyde & Time $(\mathbf{m i n})$. & Yield $(\boldsymbol{\%}))^{\mathbf{a}, \mathbf{b}}$ & Obs. & M.P. $\left({ }^{\circ} \mathbf{C}\right)$ \\
\hline 1 & Benzaldehyde & 15 & 97 & $226-230$ & $230-232^{20}$ \\
2 & 4-Methylbenzaldehyde & 19 & 94 & $263-267$ & $266-268^{20}$ \\
3 & 4-Methoxybenzaldehyde & 20 & 96 & $238-240$ & $242-244^{19}$ \\
4 & 4-Bromobenzaldehyde & 19 & 96 & $266-268$ & $265-267^{20}$ \\
5 & 4-Hydroxybenzaldehyde & 22 & 95 & $224-226$ & $222-224^{19}$ \\
6 & 4-Nitrobenzaldehyde & 10 & 97 & $227-230$ & $232-234^{19}$ \\
7 & 3-Nitrobenzaldehyde & 10 & 97 & $236-239$ & $236-238^{19}$ \\
8 & 2-Thienyl carbaldehyde & 20 & 96 & $211-213$ & $210^{19}$ \\
9 & 2-Furanyl carbaldehyde & 21 & 95 & $205-207$ & $202^{19}$ \\
10 & Cinnamaldehyde & 27 & 94 & $275-279$ & $279-281^{28}$ \\
11 & 3-Phenylpropionaldehyde & 30 & 94 & $188-191$ & $190^{17}$ \\
12 & Butyraldehyde & 33 & 94 & $121-125$ & $123^{17}$ \\
\hline
\end{tabular}

${ }^{a}$ Isolated yields. ${ }^{\mathrm{b}}$ All products are known compounds and were identified by comparison of their physical and spectral data with those of the authentic samples.

To determine the extent of sulfuric acid groups leaching from poly(AMPS-co-AA) $@ \mathrm{Fe}_{3} \mathrm{O}_{4}$ one test was performed. Poly(AMPS-co-AA) @ $\mathrm{Fe}_{3} \mathrm{O}_{4}$ was added to toluene and the mixture was stirred for $2 \mathrm{~h}$ at $90{ }^{\circ} \mathrm{C}$. Then, the catalyst was removed by using magnetic field and the filtrate was analyzed for its acid content, which showed a negligible release of the acidic sites. The filtrate was found to be inactive in the reaction of aldehydes with 4-hydroxycoumarin. Thus, this leaching test suggested that the poly(AMPS-co-AA) $@ \mathrm{Fe}_{3} \mathrm{O}_{4}$ catalyst was a true heterogeneous catalyst without significant acid moieties leaching.
Scheme 2 shows a possible mechanism for the preparation of biscoumarins using poly(AMPS-co-AA)@ $\mathrm{Fe}_{3} \mathrm{O}_{4}$. First, the acidic nature of catalyst may facilitate the enolization step of 4-hydroxycoumarin. Second, nucleophilic addition of 4-hydroxycoumarin to the activated aldehyde followed by loss of $\mathrm{H}_{2} \mathrm{O}$ generates intermediate $\mathrm{I}$, which is further activated by poly(AMPS-co-AA) @$\mathrm{Fe}_{3} \mathrm{O}_{4}$. Then, the 1,4-nucleophilic addition of a second molecule of 4-hydroxycoumarin on the activated intermediate I, in the Michael addition fashion, affords the biscoumarin product. Based on this mechanism, it is clear

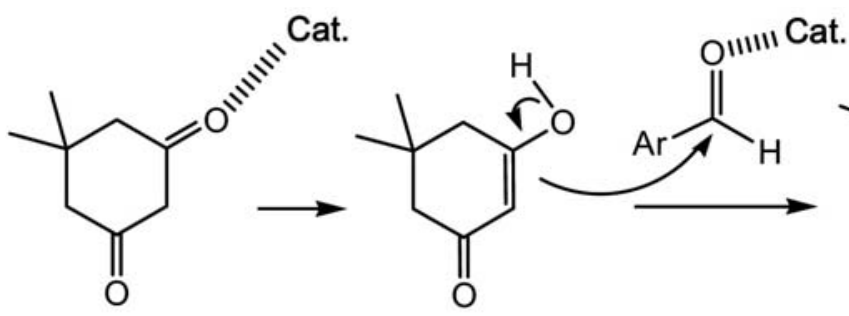<smiles>CC1(C)CC(=O)C(C(O)Br)C(=O)C1</smiles><smiles>COc1ccccc1</smiles><smiles>CCO[C@@H]1CC(C)(C)CC(=O)C1=C(Br)CC</smiles><smiles>CC1(C)CC(=O)C2=C(C1)OC1=C(C(=O)CC(C)(C)C1)C2Br</smiles><smiles>CCCCCCCCC</smiles>

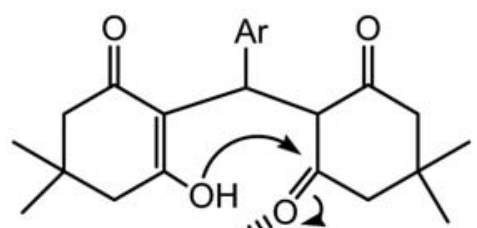<smiles>CCCC</smiles><smiles>CC1CC(=O)CC(C)(C)C1</smiles>

Cät.

(II)

Cat.: Poly (AMPS-co-AA) @ $\mathrm{Fe}_{3} \mathrm{O}_{4}$

Scheme 2. Suggested mechanism for the preparation of biscoumarins catalyzed by poly(AMPS-co-AA) @ $\mathrm{Fe}_{3} \mathrm{O}_{4}$. 
that in the cases of electron withdrawing groups present on the aromatic aldehyde (Table 1 , entries 6,7 ), the 1,4nucleophilic addition of a second molecule of 4-hydroxycoumarin on the activated intermediate $\mathrm{I}$ is more favored which can finally cause the decrease of reaction time for these types of aldehydes when reacting with 4-hydroxycoumarin. ${ }^{27,33}$ We believe that the catalytic efficiency of poly(AMPS-co-AA) @ $\mathrm{Fe}_{3} \mathrm{O}_{4}$ may be attributed to the acidic hydrogen $\left(\mathrm{SO}_{3} \mathrm{H}\right)$ as well as Lewis acid properties of $\mathrm{Fe}_{3} \mathrm{O}_{4}$ nanoparticles.

Very recently, we have introduced carbon nanotubesupported butyl 1-sulfonic acid groups as a heterogeneous catalyst for the synthesis of 1,8-dioxo-octahydroxanthenes. ${ }^{32}$ Along this line and based on the above encouraging results, we tried to examine the applicability of poly(AMPS-co-AA) @ $\mathrm{Fe}_{3} \mathrm{O}_{4}$ for the synthesis of 1,8-dioxo-octahydroxanthenes and 12-aryl-9,9-dimethyl-

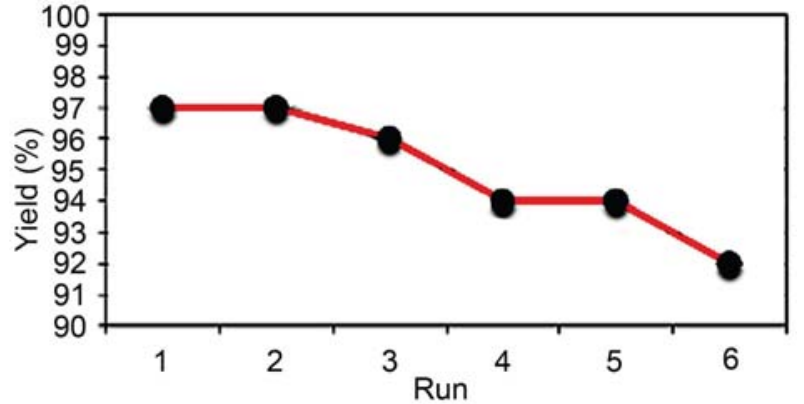

Figure 8. Recyclability of poly(AMPS-co-AA) $@ \mathrm{Fe}_{3} \mathrm{O}_{4}(0.04$ $\mathrm{mmol})$ in the reaction of benzaldehyde $(1 \mathrm{mmol})$ with 4-hydroxycoumarin $(2 \mathrm{mmol})$ in toluene at $90^{\circ} \mathrm{C}$ after $15 \mathrm{~min}$.

8,9,10,12-tetrahydrobenzo[ $a]$ xanthene-11-ones through condensation of aromatic aldehydes with dimedone and $\beta$-naphthol. We observed that 1,8-dioxo-octahydroxanthe-

Table 2: Comparison results of poly(AMPS-co-AA)@ $\mathrm{Fe}_{3} \mathrm{O}_{4}$ with other catalysts reported in the literature in the condensation of benzaldehyde with two equivalents of 4-hydroxycoumarin.

\begin{tabular}{|c|c|c|c|}
\hline Entry & Reaction conditions & Time (min.) & Yield $(\%)^{\mathrm{a}}$ \\
\hline 1 & Piperidine, EtOH, r.t. & 240 & $92^{17}$ \\
\hline 2 & Tetrabutylammonium bromide, $\mathrm{H}_{2} \mathrm{O}, 100{ }^{\circ} \mathrm{C}$ & 25 & $92^{18}$ \\
\hline 3 & $\mathrm{I}_{2}, \mathrm{H}_{2} \mathrm{O}, 100{ }^{\circ} \mathrm{C}$ & 25 & $97^{19}$ \\
\hline 4 & Sodium dodecyl sulfate, $\mathrm{H}_{2} \mathrm{O}, 60^{\circ} \mathrm{C}$ & 138 & $90^{20}$ \\
\hline 5 & 1-Buthyl-3-methylimidazolium tetrafluoroborate, $70^{\circ} \mathrm{C}$ & 120 & $84^{21}$ \\
\hline 6 & 1-Ethyl-3-(3-sulfopropyl)-benzimidazolium trifluoromethanesulfonate, $70{ }^{\circ} \mathrm{C}$ & 120 & $95^{22}$ \\
\hline 7 & $p$-Dodecylbenzenesulfonic acid/piperidine, $\mathrm{H}_{2} \mathrm{O}$, r.t. & 360 & $89^{23}$ \\
\hline 8 & 3-Methyl-1-(4-sulfonic acid)butylimidazolium hydrogen sulfate, $70^{\circ} \mathrm{C}$ & 30 & $92^{24}$ \\
\hline 9 & $\mathrm{~B}\left(\mathrm{HSO}_{4}\right)_{3}, \mathrm{EtOH} / \mathrm{H}_{2} \mathrm{O}, 70^{\circ} \mathrm{C}$ & 6 & $86^{25}$ \\
\hline 10 & Polyvinyl pyrrolidone-nickel nanoparticles, ethylene glycol, r.t. $^{\mathrm{b}}$ & 15 & $93^{26}$ \\
\hline 11 & [Poly(4-vinylpyridine)- $\left.\mathrm{BuSO}_{3} \mathrm{H}\right] \mathrm{Cl}$-x $\mathrm{AlCl}_{3}$, toluene, $90^{\circ} \mathrm{C}$ & 36 & $95^{27}$ \\
\hline 12 & [Poly(4-vinylpyridine)- $\left.\mathrm{BuSO}_{3} \mathrm{H}\right] \mathrm{HSO}_{4}$, toluene, $90^{\circ} \mathrm{C}$ & 48 & $93^{28}$ \\
\hline 13 & Cellulose sulfonic acid, $\mathrm{H}_{2} \mathrm{O}$, reflux & 120 & $90^{29}$ \\
\hline 14 & Poly(AMPS-co-AA) @ $\mathrm{Fe}_{3} \mathrm{O}_{4}$, toluene, $90^{\circ} \mathrm{C}$ & 15 & 97 \\
\hline
\end{tabular}

${ }^{\mathrm{a}}$ Isolated yields. ${ }^{\mathrm{b}}$ With 4-nitrobenzaldehyde.<smiles>[C]C1(C)CC(=O)CC(=O)C1</smiles>

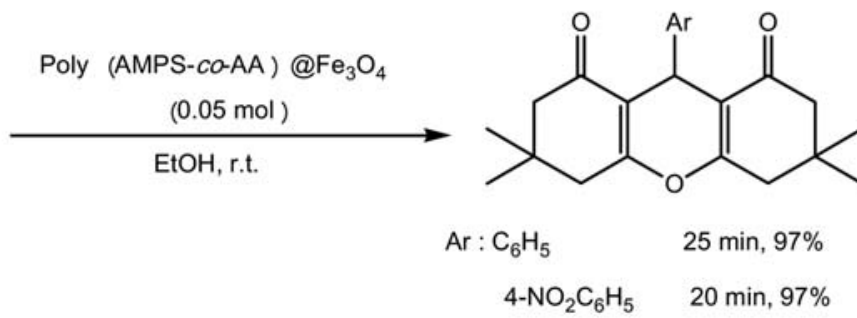

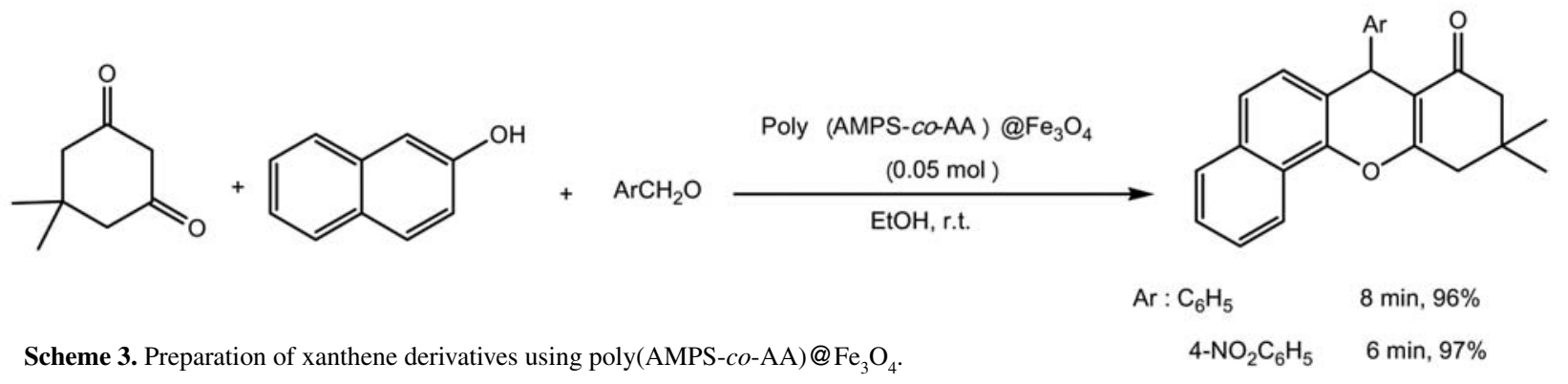


nes and 12-aryl-9,9-dimethyl-8,9,10,12-tetrahydroben$\mathrm{zo}[a]$ xanthene-11-ones were obtained in high yields in ethanol at room temperature in the presence of $0.05 \mathrm{mmol}$ of poly(AMPS-co-AA) @ $\mathrm{Fe}_{3} \mathrm{O}_{4}$ (Scheme 3). It is worth noting that, to the best of our knowledge, relatively few examples were reported on the synthesis of xanthene derivatives at room temperature. Usually, these reactions need high temperatures, long time or an additional source of energy (ultrasound or microwave irradiation). ${ }^{34-36}$

Finally, we investigated the reusability of the poly(AMPS-co-AA) @ $\mathrm{Fe}_{3} \mathrm{O}_{4}$ catalyst, and it was found that the catalyst could be completely recovered and used again at least six times without any noticeable loss of catalytic activity (Figure 8).

In comparison with selected previously known protocols employed for the synthesis of biscoumarins, poly(AMPS-co-AA) @ $\mathrm{Fe}_{3} \mathrm{O}_{4}$ showed that in addition to having the general advantages attributed to the solid catalysts it has a much higher activity evident in the terms of high yields reached after short reaction times and at mild reaction conditions (Table 2).

\section{Conclusion}

In this study the coating of $\mathrm{Fe}_{3} \mathrm{O}_{4}$ nanoparticles with sulfonated polyacrylamide has been described. Magnetization measurements showed that the obtained poly(AMPS-co-AA) $@ \mathrm{Fe}_{3} \mathrm{O}_{4}$ particles have paramagnetic properties. Poly(AMPS-co-AA) $@ \mathrm{Fe}_{3} \mathrm{O}_{4}$ showed good catalytic activity in a one-pot domino Knoevenagel-type condensation/Michael reaction between aldehydes and 4hydroxycoumarin, aromatic aldehydes with dimedone, and aromatic aldehydes with dimedone and $\beta$-naphthol. Work-up of these reactions is a "green" process because the catalyst was easily separated from the reaction media by the application of an external magnetic source. The high thermal and chemical stabilities of the catalyst, easy preparation, handling, and recycling of the catalyst, high yields achieved, and short reaction times needed are the other obvious advantages of the present method.

\section{Acknowledgement}

The authors are thankful to the Research Council of Shahrekord University and Marvdasht Branch Islamic Azad University for their partial support of this work.

\section{References}

1. R. M. Cornell, U. Schwartmann, The Iron Oxide: Structure, Properties, Reactions, Ccurrences and Uses, Wiley-VCH, Weinheim, 2003.

https://doi.org/10.1002/3527602097
2. V. Polshettiwar, R. Luque, A. Fihri, H. Zhu, M. Bouhrara, J. M. Basset, Chem. Rev. 2011, 111, 3036-3075. https://doi.org/10.1021/cr100230z

3. S. Shylesh, V. Schnemann, W. R. Thiel, Angew. Chem. Int. Ed. 2010, 49, 3428-3459. https://doi.org/10.1002/anie.200905684

4. K. R. Reddy, K. P. Lee, A. I. Gopalan, A. M. Showkat, Polym. Adv. Technol. 2007, 18, 38-43. https://doi.org/10.1002/pat.735

5. M. M. Lakouraj, E. Nazarzadeh Zare, P. Najafi Moghadam, Adv. Poly. Tech. 2014, 33, 21385 (1-7).

6. V. Panwar, S. S. Ray, S. L. Jain, Tetrahedron Lett. 2016, 57 , 5026-5032.

https://doi.org/10.1016/j.tetlet.2016.09.093

7. A. Hu, G. T. Yee, W. Lin, J. Am. Chem. Soc. 2005, 127, 12486-12487. https://doi.org/10.1021/ja053881o

8. A. Schätz, M. Hager, O. Reiser, Adv. Funct. Mater. 2009, 19, 2109-2115. https://doi.org/10.1002/adfm.200801861

9. M. A. Ghasemzadeh, J. Safaei-Ghomi, S. Zahedi, J. Serb. Chem. Soc. 2013, 78, 769-779.

10. A. Gharib, L. Vojdani Fard, N. Noroozi Pesyan, M. Roshani, Chem. J. 2015, 1, 58-67.

11. K. Karami, S. Dehghani Najvani, N. Haghighat Naeini, P. Hervés, Chin. J. Catal. 2015, 36, 1047-1053. https://doi.org/10.1016/S1872-2067(15)60837-3

12. M. A. Ghasemzadeh, Acta Chim. Slov. 2015, 62, 977-985. https://doi.org/10.17344/acsi.2015.1501

13. M. A. Ghasemzadeh Quim. Nova, 2017, 40, 47-53.

14. A. Maresca, A. Scozzafava, C. T. Supuran, Bioorg. Med. Chem. Lett. 2010, 20, 7255-7258. https://doi.org/10.1016/j.bmcl.2010.10.094

15. N. Vukovic, S. Sukdolak, S. Solujic, N. Niciforovic, Food Chem. 2010, 120, 1011-1018. https://doi.org/10.1016/j.foodchem.2009.11.040

16. F. Carta, A. Maresca, A. Scozzafava, C. T. Supuran, Bioorg. Med. Chem. 2012, 20, 2266-2273. https://doi.org/10.1016/j.bmc.2012.02.014

17. K. M. Khan, S. Iqbal, M. A. Lodhi, G. M. Maharvi, Z. Ullah, M. I. Choudhary, A. U. Rahmana, S. Perveen, Bioorg. Med. Chem. 2004, 12, 1963-1968. https://doi.org/10.1016/j.bmc.2004.01.010

18. J. Khurana, M. S. Kumar, Tetrahedron Lett. 2009, 50, 4125-4127. https://doi.org/10.1016/j.tetlet.2009.04.125

19. M. Kidwai, V. Bansal, P. Mothsra, S. Saxena, R. K. Somvanshi, S. Dey, T. P. Singh, J. Mol. Catal. A Chem. 2007, 268, 76-81.

https://doi.org/10.1016/j.molcata.2006.11.054

20. H. Mehrabi, H. Abusaidi, J. Iran. Chem. Soc. 2010, 7, 890-894. https://doi.org/10.1007/BF03246084

21. J. M. Khurana, S. Kumar, Monatsh. Chem. 2010, 141, 561564. https://doi.org/10.1007/s00706-010-0306-4

22. W. Li, Y. Wang, Z. Wang, L. Dai, Y. Wang, Catal. Lett. 2011, 141, 1651-1658. 
https://doi.org/10.1007/s10562-011-0689-9

23. A. Kumar, M. K. Gupta, M. Kumar, Tetrahedron Lett. 2011, 52, 4521-4525. https://doi.org/10.1016/j.tetlet.2011.06.040

24. N. Tavakoli-Hoseini, M. M. Heravi, F. F. Bamoharram, A. Davoodnia, M. Ghassemzadeh, J. Mol. Liq. 2011, 163, 122-127. https://doi.org/10.1016/j.molliq.2011.08.007

25. Z. Karimi-Jaberi, M. R. Nazarifar, B. Pooladian, Chin. Chem. Lett. 2012, 23, 781-784.

https://doi.org/10.1016/j.cclet.2012.05.003

26. J. M. Khurana, K. Vij, J. Chem. Sci. 2012, 124, 907-912. https://doi.org/10.1007/s12039-012-0275-8

27. K. Parvanak Boroujeni, P. Ghasemi, Catal. Commun. 2013, 37, 50-54. https://doi.org/10.1016/j.catcom.2013.03.025

28. K. Parvanak Boroujeni, P. Ghasemi, Z. Rafienia, Monatsh. Chem. 2014, 145, 1023-1026. https://doi.org/10.1007/s00706-014-1156-2

29. M. Sedighi, N. Montazeri, Adv. Stud. Biol. 2015, 7, 89-95. https://doi.org/10.12988/asb.2015.41160
30. N. Jagadishbabu, K. Shivashankar, J. Heterocycl. Chem. 2017, 54, 1543-1549. https://doi.org/10.1002/jhet.2742

31. F. Gholamian, M. Shabanian, M. Shahrokh, J. Clust. Sci. 2013, 24, 177-188.

32. K. Parvanak Boroujeni, Z. Heidari, R. Khalifeh, Acta Chim. Slov. 2016, 63, 602-608. https://doi.org/10.17344/acsi.2016.2291

33. E. V. Anslyn, D. A. Dougherty, Modern Physical Organic Chemistry, University Science Books, California, 2006.

34. T.-S. Jin, J.-S. Zhang, J.-C. Xiao, A.-Q. Wang, T.-S. Li, Ultrason. Sonochem. 2006, 13, 220-224. https://doi.org/10.1016/j.ultsonch.2005.04.002

35. K. Venkatesan, S. S. Pujari, R. J. Lahoti, K. V. Srinivasan, Ultrason. Sonochem. 2008, 15, 548-553. https://doi.org/10.1016/j.ultsonch.2007.06.001

36. C. S. Sundar, K. U. M. Rao, N. B. Reddy, M. V. N. Reddy, S. S. Prasad, C. S. Reddy, Catal. Sci. Technol. 2012, 2, 13821385. https://doi.org/10.1039/c2cy20041d

\section{Povzetek}

$\mathrm{S}$ polimerizacijo ustreznih monomerov in z nadaljnjo reakcijo $\mathrm{s} \mathrm{Fe}_{3} \mathrm{O}_{4}$ nanodelci smo pripravili magnetitne delce $\mathrm{s}$ sulfoniranim poliakrilamidnim ovojem. Karakterizacijo dobljenega katalitskega materiala smo izvedli s Fourierjevo transformacijsko infrardečo spektroskopijo (FT-IR), termično gravimetrijo (TGA), vrstično elektronsko mikroskopijo (SEM), energijsko disperzijsko spektroskopijo (EDS), rentgensko difrakcijo (XRD) in vibracijsko magnetometrijo (VSM). Ugotovili smo, da pripravljeni polimer vsebuje $1.1 \mathrm{mmol}$ na gram kislih $\mathrm{SO}_{3} \mathrm{H}$ ostankov. Katalitsko učinkovitost polimera smo raziskali na primeru sinteze biskumarinskih derivatov, ki smo jih pripravili z dvokomponentno enolončno domino Knoevenaglovo kondenzacijo s sledečo Michaelovo reakcijo med aldehidi in 4-hidroksikumarinom. Biskumarine smo pripravili z visokimi izkoristki in s kratkimi reakcijskim časi. Izolacije so bile zelo enostavne. Katalizatorji so stabilni (pri sobnih pogojih), z njimi je enostavno ravnati in jih je moč ponovno uporabiti. 